\title{
The Role of National Parliaments in the European Union
}

\author{
Oskar Josef Gstrein and Darren Harvey*
}

Table of Contents
A. Background
B. Evaluation of Procedure to Date 339
C. The First Yellow Card 341
I. How the Yellow Card was issued 343
II. The Scope and Content of Subsidiarity Review 346
D. The Second Yellow Card 348
I. National Parliaments' Observations and the Response of the Commission 350
II. The problem with Ex Post Subsidiarity Review 352
E. Possible Solutions $\quad 354$
I. Procedural 354
II. Substantive: A Common Understanding of Subsidiarity 356
F. Looking to the future $\quad 357$
G. Conclusion $\quad 358$

\begin{abstract}
A. Background
Under the treaties establishing the European Communities, national parliaments neither had, nor were in search of, a formally subscribed function in EU affairs. ${ }^{1}$ This was in large part because until 1979 members of the European Parliament were not directly elected by the people of Europe but were instead members of national parliaments who had been designated as members of the European Parliament. As a result, national parliaments were in a strong position at the European level and although some national parliaments (German,

* MMag. Oskar Josef Gstrein, LL.M. is a research assistant and PhD candidate at the Jean-MonnetChair of Prof. Dr. Thomas Giegerich, LL.M. at the Europa-Institut of Saarland University. Darren Harvey LL.B, LL.M. is also a research assistant at the above mentioned Chair of Prof. Giegerich and a prospective Certificate of Postgraduate Study (Law) candidate at the University of Cambridge. This paper is an extended version of published written evidence provided by the authors to the United Kingdom House of Lords in response to a call for evidence concerning the role of national parliaments in the European Union. See Evidence of Gstrein/Harvey, House of Lords European Union Select Committee, The Role of National Parliaments in the European Union, Written Evidence, pp. 53-59, www.parliament.uk/documents/lords-committees/eu-select/Role\% 20of\%20national\%20parliaments/nat-parl-evidence-volume.pdf (25/6/2014).

1 Granat, Institutional Design of the Member States For the Ex Post Subsidiarity Scrutiny, Luis Guido Carli Working Paper Series, 2013, p. 2.
\end{abstract}


Belgian, Italian and Dutch) did establish European Committees early on in the process of European integration, these committees had marginal influence on European affairs. ${ }^{2}$

Over time, however, as more and more competences shifted from the national to the EU level via successive treaty amendments, the proper role for national parliaments in the process of European integration became a more pressing issue. Because of the Council's role as the most important EU decision making institution, the decision making process of the EU is heavily influenced by national governments, and as more powers were transferred to the European level this deprived national parliaments of direct powers on the adoption of legislative acts in those fields in which powers had been transferred. ${ }^{3}$

One attempt at solving the seemingly ever increasing gap in democratic legitimacy in Europe was the introduction of new rules for increased responsibility of government members in some Member States. ${ }^{4}$ These changes reflect the long standing belief that national parliaments should be able to control the activities of the executive branch of their nation in Brussels by having the possibility to ask what stance their ministers intend on taking before and after a vote on a particular issue. Furthermore, this need for enhanced accountability of the executive has led to the possibility, in some cases, of obliging ministers to behave in a certain way when casting their vote vis-à-vis European legislative proposals.

Gradually, the EU Treaties did come to recognize the role of national parliaments, first through a Declaration on the role of national parliaments in the EU (annexed to the final act of the Maastricht Intergovernmental Conference (IGC) $)^{5}$ and then in Protocols (annexed to the Treaties by the Amsterdam and Nice Treaties). ${ }^{6}$

The final text of the Treaty Establishing a Constitution for Europe, which ultimately failed to become law on accounts of the Dutch and French vetoes, explicitly mentioned the role of national parliaments in the body of the treaty text itself for the first time. It was seen as necessary to give national parliaments an enhanced role in the operations of the European Union on accounts of the fact that the European Parliament had not fully succeeded in providing the solution to the well documented problems of democratic legitimacy in the European Union. ${ }^{7}$ Accordingly, the Constitutional Treaty proposed giving national parlia-

2 Ibid.

3 Piris, The Lisbon Treaty: A Legal and Political Analysis, Cambridge Studies in European Law and Policy, 2010, p. 123; Goldini, The Early Warning System and the Monti II Regulation: The Case for a Political Interpretation, European Constitutional Law Review 2014, pp. 90-108; Auel/Rittberger, The European Parliament, National Parliaments and European Integration, in: Richardson (ed.), European Union, Power and Policy Making, 3rd ed. 2006, p. 136 et seq.

$4 \mathrm{Cf}$. for Germany Article 23 German Federal Constitution (GG) and additionally the Gesetz über die Zusammenarbeit von Bundesregierung und Deutschem Bundestag in Angelegenheiten der Europäischen Union (EUZBBG) of 4/7/2013, BGB1. 2013 I, 2170; Gesetz über die Zusammenarbeit von Bund und Ländern in Angelegenheiten der Europäischen Union of 12/3/1993, BGB1. 1993 I, 313, FNA 170-3, last changed by Article 1 ÄndG of 22/9/2009, BGB1. 2009 I, 3031. See also the first "ESM-ruling" of the Federal Constitutional Court of 2012, Graf von Kielmannsegg, Parlamentarische Informationsrechte in der Euro-Rettung - Anmerkung zum ersten ESM-Urteil des BVerfG vom 19.6.2012, EuR 2012, p. 654.

5 In this Declaration the IGC underlined the importance of encouraging "greater involvement of national parliaments in the activities of the EU", see Piris, (fn. 3), p. 124.

6 Ibid.

7 Ibid., p. 125. 
ments a role in scrutinising EU legislation's compliance with the principle of subsidiarity via the so-called "yellow card" procedure (see below). ${ }^{8}$

It was not until the coming into force of the Lisbon Treaty, however, that, for the first time in the history of the European Union, national parliaments were mentioned in the main text of the Union's founding Treaties. According to the Treaty of Lisbon, the main task of national parliaments with regards to the European decision-making process is to "contribute actively to the good functioning of the Union." 9 In order to carry out this task effectively, the Lisbon Treaty conferred certain rights on national parliaments including the right to receive information directly from the EU institutions (i.e. not through their own government) and a direct role in checking that the EU institutions respect the principle of subsidiarity. ${ }^{10}$

Despite rejecting the idea of giving the Member States' parliaments a position within the legislative triangle of the $\mathrm{EU}^{11}$ by introducing a "red card procedure" that would allow them to veto EU legislative proposals, ${ }^{12}$ their role was nevertheless heightened to a potentially large extent by the changes in the Lisbon Treaty with the setting up of the Early Warning Mechanism in Protocol (No 2). ${ }^{13}$ This Protocol, in conjunction with Article 5(3) TEU, provides national parliaments with the possibility to directly inform the Commission, or other EU bodies competent to initiate legislation in particular fields, whenever a legislative proposal does not, in their opinion, comply with the principle of subsidiarity. ${ }^{14}$

The Early Warning Mechanism as set out in Protocol (No 2) obliges the EU institution initiating legislation, almost always the European Commission, to send draft legislative acts to national parliaments at the same time as it sends them to the Council of Ministers and the European Parliament. Following receipt of the proposal, national parliaments then have a period of eight weeks ${ }^{15}$ in which to submit a reasoned opinion to the Presidents of the European Parliament, the Council and the Commission stating why it considers that the draft in question does not comply with the principle of subsidiarity. Each parliament is assigned two votes, meaning that one vote is apportioned to each chamber in bicameral legislatures.

If one third or more of the total votes allocated to national parliaments indicate, through their reasoned opinions, that a proposed piece of legislation is in breach of the principle of subsidiarity, the so-called "yellow card procedure" becomes effective. In cases where a

8 Article I-11(3) Treaty Establishing a Constitution for Europe.

9 Article 12 TEU.

10 See Article 5 TEU and Protocol (No 2).

11 This triangle consists of the Council of the European Union, the European Parliament and the European Commission, who are the traditional players in drafting and adopting legislative acts in the European Union.

12 Piris, (fn. 3), p. 128.

13 Puntscher Riekmann, Constitutionalism and Representation: European Parliamentarism in the Treaty of Lisbon, in: Dobner/Loughlin (eds.), The Twilight of Constitutionalism, Oxford Constitutional Theory 2010, pp. 134-136.

14 See generally Craig/De Burca, EU Law: Text, Cases and Materials, 5th ed. 2011, p. 96; see also Streinz/Ohler, Der Vertrag von Lissabon zur Reform der EU, 2010, p. 73 et seq.

15 A version of the Early Warning Mechanism had also been proposed in the failed Constitutional Treaty but only gave national parliaments six weeks in which to scrutinize EU legislation. See Piris, (fn. 3), p. 127. 
draft legislative act is submitted on the basis of Article 86 TFEU (the area of freedom, security and justice) the total number of votes required from national parliaments to trigger a yellow card procedure shall be one quarter (as opposed to one third) of the total number of votes assigned to national parliaments.

Should the requisite thresholds be met under this procedure, the author of the draft legislative act must review the proposal and may then decide to maintain, amend or withdraw the draft. Reasons must be given for this decision. ${ }^{16}$

In addition to the yellow card procedure, an "orange card" procedure may also be initiated under Protocol (No 2). This additional procedure did not feature in the aforementioned failed Constitutional Treaty and was introduced at behest of the Netherlands during the negotiations leading up to the adoption of the Lisbon Treaty. ${ }^{17}$ Here, within the framework of the ordinary legislative procedure, a majority of votes assigned to national parliaments indicating a breach of subsidiarity will lead to the Commission having to review its proposal. If the Commission chooses to maintain its proposal, it will have to set out in a reasoned opinion why it considers the proposal to be compatible with the principle of subsidiarity. This proposal, along with the reasoned opinions of national parliaments that led to the triggering of the "orange card procedure", must be submitted to the Union legislator (Parliament and Council). If, by a majority of $55 \%$ of the members of the Council, or a majority of the votes cast in the European Parliament, the legislator is of the opinion that the proposal is not compatible with the principle of subsidiarity, the legislative proposal shall not be given further consideration. ${ }^{18}$

It has to be pointed out, however, that there is no way for national parliaments to stop an ongoing legislative procedure by the rules laid down in Protocol (No 2). Put in simple terms, there is no "red card".

By including this innovative mechanism for national parliaments in the EU legal order it was noted that the Lisbon Treaty had, to a certain extent at least, implemented legal scholarship's insight that adherence to the principle of subsidiarity would be most effectively secured through procedures providing ex ante monitoring. ${ }^{19}$

That being said, from its inception opinion was divided as to the potential impact of the new Early Warning Mechanism on the European legislative process. From a theoretical perspective, some took the view that this new role for national parliaments constituted a "virtual third chamber" alongside the Council and the European Parliament and that it would lead to collective decision making on legislative proposals. ${ }^{20}$ In this regard one could say that the collective monitoring introduced by the Treaty of Lisbon intended to change the position of parliaments from isolated individual actors in European Union affairs to a

16 Article 7(2) of Protocol (No 2) on the Application of the Principles of Subsidiarity and Proportionality.

17 Piris, (fn. 3), p. 129.

18 Article 7(3) of Protocol (No 2) on the Application of the Principles of Subsidiarity and Proportionality. See also Schutz, Subsidiarity after Lisbon: Reinforcing the Safeguards of Federalism?, Cambridge Law Review 68 (2009), pp. 525-536.

19 Von Bogdandy/Bast, The Federal Order of Competences, in: Principles of European Constitutional Law, 2nd ed. 2011, p. 303.

20 Cooper, A 'Virtual Third Chamber' for the European Union?, National Parliaments After the Treaty of Lisbon, ARENA Working Paper, University of Oslo, 2012, pp. 441-465. 
proactive horizontal bloc. ${ }^{21}$ It was submitted that national parliaments would form a kind of "meta-parliament" at the EU level since when they adopted reasoned opinions raising subsidiarity objections to a legislative proposal, they would in effect be casting votes against that proposal, and when a yellow or orange card threshold was reached, this would in effect be a collective decision. ${ }^{22}$

In contrast, others were not so enthusiastic about the prospects of the Early Warning Mechanism, predicting that national parliaments would not form any type of collective and that each national parliamentary chamber would conduct scrutiny on an individual basis wherein the scrutiny activities of other parliaments would be irrelevant. Accordingly, far from creating a role for national parliaments as some sort of meta-parliament, those of a more sceptical persuasion were of the view that even if the yellow card threshold was reached, it would simply be "a coincidental sum of otherwise unrelated events." 23

Today, the Early Warning Mechanism has been in force for a period of around four years and with the benefit of this lapse in time one may appraise the impact that the mechanism has had upon the process of European integration - something that those prophesising about its expected success or failure were unable to do.

\section{B. Evaluation of Procedure to Date}

Although theoretically ground-breaking and exhibiting considerable potential to alter the balance of legislative power in the EU in favour of national parliaments, the results of the Early Warning Mechanism in practice since the coming into force of the Lisbon Treaty in 2009 have been disappointing.

According to the most recent Commission report, the total number of opinions received from national Parliaments in 2012 rose to 663; this represented an increase of $7 \%$ as compared with 2011 (622), but a much smaller increase than in previous years $(55 \%$ in 2010 , $60 \%$ in 2011). ${ }^{24}$ However, of these 663 only 70 were in the form of reasoned opinions under the Early Warning Mechanism in Protocol (No 2). ${ }^{25}$ Worse still, in a European Union consisting of 27 (now 28) Member States with 40 national parliamentary chambers (on account of there being a mixture of unicameral and bicameral national parliaments) $15 \mathrm{such}$ chambers failed to provide a single reasoned opinion on proposed EU legislation during $2012 .{ }^{26}$ This data clearly indicates that there are widely different approaches to, and understandings of, the Early Warning Mechanism in the different parliamentary chambers.

21 Cygan, National Parliaments within the EU Polity - no Longer Losers but Hardly Victorious, ERA Forum 12 (2012), p. 527.

22 Cooper, A Yellow Card for the Striker: How National Parliaments Defeated EU Strikes Regulation, 2012, p. 19.

23 Kiiver, The National Parliaments in the European Union: A Critical View on EU ConstitutionBuilding, 2006, p. 164.

24 Report from the European Commission, Annual Report 2012 on relations between the European Commission and National Parliaments, p. 4.

25 Ibid.

26 Ibid., p. 9. 
Furthermore, when analyzing the "Annual report of the European Commission on relations between the European Commission and national parliaments" 27 and the "Annual report on subsidiarity and proportionality" 28 since 2010 it is clear to see that the Early Warning Mechanism has made incredibly little impact. In fact, as is stated in the aforementioned documents, the "yellow-card" procedure had, until very recently, only been triggered once since its introduction and there has to date been no instance of an "orange card" from national parliaments. ${ }^{29}$

Evidently, therefore, there would appear to be a fundamental disconnect between national parliaments and the European legislative process with democratically elected representatives of Member States routinely abstaining from exercising their right to ensure proposed EU legislation complies with the principle of subsidiarity. Moreover, the large decrease in the growth rate of measures taken annually by national parliaments can be interpreted as a realisation of the fact that their efforts in previous years have been generally ineffective.

When considering the reasons behind the Early Warning Mechanism's truly underwhelming impact to date, it is submitted that several general difficulties may be highlighted: ${ }^{30}$

- Incentive Problems: The reluctance of majoritarian parliaments to challenge their government's position on EU affairs and the perception that there are little electoral benefits to be gained from engaging in EU affairs.

- Problems in the conception and vision of political measures: These manifest themselves in a significant number of politicians and political parties who face severe problems when aiming to transform their political concepts and goals onto the European scale. For instance, it will be clear for a Member of Parliament who is a member of the British Labour Party what the basic pillars of his parties' social policy are. However, since this policy is based on national considerations and aims for national solutions, it fails to integrate into a larger European context. Additionally, the European level is the framework in which economic entities active on the UK market operate. For them, the internal market of the EU is the main point of reference, not the national economy. Hence, a gap in political action and social reality becomes visible. ${ }^{31}$ This is only to a small extent an issue of conflicting interests between the Union and individual Member States. It is to a much larger extent the result of a failure to create modern, coherent and sound national political concepts accounting for the consequences of being in a single market. Such political visions will only face the actual challenges if - in their effect - they reach out across national horizons and offer solutions for the European level, the level at which these socio-economic phenomena are created. ${ }^{32}$

27 COM (2013) 565 final; COM (2012) 375 final; COM (2011) 345 final.

28 Ibid.; COM (2013) 566 final; COM (2012) 373 final; COM (2011) 344 final.

29 Ibid.; COM (2013) 566 final, p. 6 et seqq.

30 Gstrein/Zalewska, National parliaments and their role in European integration: The EU's democratic deficit in times of economic hardship and political insecurity, Bruges political research papers 28/2013, p. 12; Cooper, (fn. 22), p. 10.

31 Graser, Einmal mehr: Zur Europäisierung der Sozialpolitik, EuR-Beiheft 1/2013, pp. 15-31.

32 Gstrein/Harvey, House of Lords European Union Select Committee, The Role of National Parliaments in the European Union, Written Evidence, 2013, p. 54. 
- Logistical Problems: The short eight week deadline for submissions and the high volume of legislative proposals to scrutinize combined with the lack of effective mechanisms to coordinate the national parliaments' actions as required to initiate the procedure. In this regard one can say that the observation of the German Federal Constitutional Court that the effectiveness of the Early Warning Mechanism "depends on the extent to which the national parliaments will be able to make organizational arrangements that place them in a position to make appropriate use of the mechanism within the short period of eight weeks" has proved incredibly prescient. ${ }^{33}$ It has proved exceptionally difficult to coordinate the various national parliaments to act in concert and achieve the voting thresholds required for a yellow or orange card ${ }^{34}$ and this is because each parliament tends to work according to its own timetable, and according to its own unique set of procedures. ${ }^{35}$

- Weakness inherent in the subsidiarity review: The mechanism only offers an opportunity for ex ante control and, as is made clear from the wording of Protocol (No 2), the Commission is under no obligation to withdraw its proposal should a yellow or orange card be issued from national parliaments. ${ }^{36}$ This lack of a "red card" for national parliament's reasoned opinions to stop the legislative procedure results in the existing Protocol (No 2) procedure being nothing more than a mere symbolic gesture by providing national parliaments solely with the opportunity to deliver a non-binding opinion. This is an issue that became all the more problematic recently when the second yellow card was issued by national parliaments.

Despite these seemingly insurmountable problems it is submitted that the potential for effective action within the current institutional framework of the EU was amply demonstrated by the exceptionally high level of inter-parliamentary dialogue and cooperation that preceded the first - and until recently only - issuance of a yellow card to the EU by national parliaments, and this perhaps gives some encouragement going forward. ${ }^{37}$

\section{The First Yellow Card}

On 21 March 2012, the EU Commission published a proposal for a Council regulation "On the exercise of the right to take collective action within the context of the freedom of establishment and the freedom to provide services". ${ }^{38}$ The Commission proposal - inspired

33 BVerfG, 2 BvE 2/08, 2 BvE 5/08, 2 BvR 1010/08, 2 BvR 1022/08, 2 BvR 1259/08, 2 BvR 182/09, decision of 30/6/2009 - Treaty of Lisbon, para. 305.

34 Craig, The Lisbon Treaty - Law, Politics, and Treaty Reform, 2011, p. 186.

35 Cooper, (fn. 22), p. 5.

36 The Commission must only review its proposal and then decide whether to maintain, amend or withdraw it. Reasons must however be given in support of the Commission's decision.

37 For an overview of the communication and interaction between various national parliaments in the run up to the yellow, see Cooper, (fn. 22), pp. 4-14.

38 COM (2012) 130 final; for an analysis see Bruun/Bücker, Der Monti II Verordnungsvorschlag der EU Kommission, NZA 2012, p. 1136; Bruun/Bücker, European Economic, Employment and Social Policy, Trade Union Institute Policy Brief No. 4/2012; Rocca, The Proposal for a (so called) Monti II Regulation on the Exercise of the Right to Take Collective Action Within the Context of The Freedom of Establishment and The Freedom to Provide Services, Changing Without Reversing, Regulating Without Affecting, European Labour Law Journal 2012, pp. 19-34. 
by a report in May 2010 by former Commissioner Mario Monti ${ }^{39}$ which led to it being informally named the "Monti II Regulation" - pursued the goal of

"lay[ing] down the general principles and rules applicable at Union level with respect to the exercise of the fundamental right to take collective action within the context of the freedom of establishment and the freedom to provide services". ${ }^{40}$

As the Commission stated in the explanatory memorandum accompanying its proposal, the regulation sought to address the "tensions between the freedoms to provide services and of establishment, and the exercise of fundamental rights such as the right of collective bargaining and the right to industrial action" as exposed by the CJEU's decisions in Viking and Laval. ${ }^{41}$ In putting forward its proposal, the Commission explicitly acknowledged the impact that these decisions had had in the EU legal order,

"in particular on the consequences of the freedom to provide services and freedom of establishment for the protection of workers' rights and the role of trade unions in protecting workers' rights in cross-border situations". ${ }^{42}$

To address these concerns, ${ }^{43}$ the Commission took the view that EU legislation which would set the framework for permitted industrial action at the EU level was

"the most effective and efficient solution to address the specific objective [of] reducing tensions between national industrial relation systems and the freedom to provide services". ${ }^{4}$

As a legal basis for its proposal, the Commission argued that the regulation should be based on the so-called flexibility clause as set out in Article 352 TFEU, which states that:

"If action by the Union should prove necessary, within the framework of the policies defined in the Treaties, to attain one of the objectives set out in the Treaties, and the Treaties have not provided the necessary powers, the Council, acting unanimously on a proposal from the Commission and after obtaining the consent of the European Parliament, shall adopt the appropriate measures."

According to the Commission explanatory memorandum, the use of this provision was necessary on accounts of there being a lack of explicit provision in the Treaty for the necessary powers. ${ }^{45}$ Furthermore, in addition to a perceived lack of explicit competence,

39 Monti, A New Strategy for the Single Market at the Service of Europe's Economy and Society, Report to the President of the European Commission José Manuel Barroso, http://ec.europa.eu/ bepa/pdf/monti_report_final_10_05_2010_en.pdf (25/6/2014).

40 Article 1(1) of proposed Monti II Regulation.

41 Commission Explanatory Memorandum on the Proposal for a Council Regulation on the exercise of the right to take collective action within the context of the freedom of establishment and the freedom to provide services, p. 8 .

42 Ibid., p. 5.

43 Novitz, A human rights analysis of the Viking and Laval judgments, Cambridge Yearbook of European Legal Studies 10 (2007-2008), p. 541 et seq.; Davies, One step forward, two steps back?, The Viking and Laval cases in the CJEU, Industrial Law Journal 37 (2008), pp. 126-148; Goldini, (fn. 3), p. 3.

44 Commission Explanatory Memorandum, (fn. 41), p. 9; Goldini, (fn. 3), p. 3.

45 Ibid., p. 11. 
Article 153(5) TFEU seemed to exclude EU action from the field of the right to strike. ${ }^{46}$ According to the Commission

"Article 153(5) TFEU excludes the right to strike from the range of matters that can be regulated across the EU by way of minimum standards through directives. However, the Court (CJEU) rulings have clearly shown that the fact that article 153 does not apply to the right to strike does not as such exclude collective action from the scope of EU law." 47

The Commission thus sought to bypass the prohibition in Article 153 TFEU by interpreting it as only precluding the harmonization of national labour laws while leaving in place the EU competence to

"clarify the general principles and EU rules applicable to the exercise of the fundamental right to take industrial action within the context of the single market." ${ }^{\prime 4}$

In terms of substantive content, the proposed Monti II Regulation first set out that the regulation would not affect, in purely internal situations,

"the exercise of fundamental rights as recognized in the Member States, including the right or freedom to strike or to take other action covered by the specific industrial relations systems in Member States in accordance with national law and practices." 49

Then, in Article 2, the proposed regulation provided that

"the exercise of the freedom of establishment and the freedom to provide services enshrined in the Treaty shall respect the fundamental right to take collective action, including the right or freedom to strike, and conversely, the exercise of the fundamental right to take collective action, including the right or freedom to strike, shall respect these economic freedoms."

As Fabbrini and Granat have noted, this provision seemed to largely restate the general principle of proportionality - the standard tool used to reconcile different, conflicting constitutional interests - in the same manner as the CJEU case law in this field. Accordingly, it was difficult to see how this provision of the proposed Monti II Regulation was likely to trigger a change in the case law of the Court and enhance the protection of the right to strike. 51

\section{How the Yellow Card was issued}

As was previously mentioned, any effort to coordinate the various national parliaments of the EU to act in concert to achieve a yellow card is presented with a host of logistical problems since each parliament tends to work slowly according to its own timetable and

46 Fabbrini/Granat, Yellow card, but no foul: The role of the national parliaments under the subsidiarity protocol and the Commission proposal for an EU regulation on the right to strike, Common Market Law Review 50 (2013), p. 132; Goldini, (fn. 3), p. 5.

47 Commission Explanatory Memorandum, (fn. 41), p. 11.

48 Ibid., p. 10.

49 Article 1(2) of proposed Monti II Regulation.

50 Article 2 of proposed Monti II Regulation.

51 Fabbrini/Granat, (fn. 46), p. 134; see also Goldini, (fn. 3), p. 4. 
according to its own unique set of procedures. Furthermore, all of the national parliaments are formally equal under the Early Warning Mechanism with no internal structure of leadership, no speaker, no government or opposition and no parties. This means that, since all actions in the Early Warning Mechanism are voluntary, if there is to be a yellow card, then it must be the result of a spontaneous, self-organizing and bottom-up process. ${ }^{52}$ How this unsatisfactory situation could be improved is currently under discussion in several Member States. ${ }^{53}$

Despite these problems, in the case of the Monti II Regulation, the Danish Folketing seized the initiative and was the first to move to adopt a reasoned opinion with its clear intention being that of trying to influence other parliaments to adopt reasoned opinions as well. The political decision to adopt a reasoned opinion was made unanimously on 20 April 2012. It was formally adopted on 3 May, making it the first parliamentary chamber to do so. ${ }^{54}$

Following the Danish parliament's reasoned opinion on 20 April, national parliamentarians were then given a rather fortunate opportunity to discuss the Monti II proposal faceto-face at the meeting of the Conference of Community and European Affairs Committees of Parliaments of the European Union (COSAC) in Copenhagen on 22 to 24 April. This meeting coincidentally fell in the middle of the eight week scrutiny period afforded to national parliaments for the Monti II Regulation and was hosted by the Danish parliament on accounts of COSAC meetings always being hosted by the parliament of the Member State holding the Council presidency, as Denmark did in the first half of 2012.55

The reasoned opinion of the Danish parliament was hastily translated into English so that it could be circulated to other parliamentary delegations who were attending the COSAC meeting in Copenhagen. However, the Danish parliament did not use their limited agenda setting powers as the chair of the COSAC meeting to put the proposed Monti II Regulation, or even more general subsidiarity issues, onto the agenda of the COSAC meeting. ${ }^{56}$ Instead, the Danish delegation used the occasion to informally approach members of other parliaments to tell them that they were going to formally adopt a reasoned opinion in opposition to Monti II, and to enquire as to whether they might consider doing the same. ${ }^{57}$ As Cooper has noted,

"Whether it made a difference that such unofficial advances came from the nominal chair of the meeting is impossible to know. But it is likely that the fact that the COSAC meeting took

52 Cooper, (fn. 22), p. 6.

53 House of Lords European Union Committee, 9th Report of Session 2013-2014, The role of national parliaments in the European Union, pp. 19, 54.

54 See Danish Parliament European Affairs Committee, Reasoned Opinion of 3/5/2013, www.epsu. org/IMG/pdf/Reasoned_Opinion_on_Monti_II_-_KOM_2012_130_Courtesy_Translation_ EN.pdf (25/6/2014).

55 According to the website for the COSAC meeting in Copenhagen, Denmark in April 2012, the session focused on the re-launching of the single market and thus did not officially concern itself with matters of subsidiarity scrutiny by national parliaments, see www.cosac.eu/denmark2012/ (25/6/2014). See also Cooper, (fn. 22), p. 7.

56 See Minutes of COSAC XLVII Meeting, Copenhagen of 22-24/4/2013, www.cosac.eu/denmark 2012/plenary-meeting-of-the-xlvii-cosac-22-24-april-2012/ (25/6/2014).

57 Cooper, (fn. 22), p. 7. 
place at all, allowing the participants in the EWM [Early Warning Mechanism] to meet on a face-to-face basis, spurred some NPs [national parliaments] - the Latvian parliament, for example - to pass reasoned opinions which they would not have otherwise." 58

The coordinating role of the representatives to national parliaments was also crucial in the build up to the issuance of the first ever yellow card under the Early Warning Mechanism and thus merits consideration. Currently every national parliament except Slovakia has at least one staff representative to the EU institutions. ${ }^{59}$ The most basic role of these representatives, who are civil servants from their home parliament, is as conduits of information, telling people back home what is going on in Brussels and vice versa. These representatives all work in close proximity to one another, meeting on a weekly basis at offices provided by the European Parliament which are also attended by officers from both the Inter-parliamentary EU information exchange (IPEX) and COSAC but not from other EU institutions, unless they are otherwise invited. At these meetings the representatives of national parliaments discuss a variety of issues including matters of subsidiarity control by the national parliaments. This group is also continuously in contact with one another through a common email list and can share documents privately on a common server. Having this group in place, therefore, makes it possible for a national parliament to know, in real time, the state of play in other national parliaments of the subsidiarity review of a given proposal.

Finally, on the day of the deadline for the eight week scrutiny period under the Early Warning Mechanism (22 May) enough reasoned opinions were issued by national parliaments to trigger the yellow card procedure. Reasoned opinions were issued by twelve national parliaments: seven unicameral (fourteen votes) and five bicameral (five votes), thus equalling nineteen votes. ${ }^{60}$ In early June the Commission confirmed that the yellow card threshold had been reached in the case of the proposed Monti II regulation. ${ }^{61}$

From the above, one may be inclined to suggest that, from a procedural perspective at least, the manner in which national parliaments managed to first collectively engage with, and then actively oppose, the Monti II Regulation gives rise to the hope that the current institutional framework may not be entirely dysfunctional. In this regard, it is possible to view the levels of parliamentary cooperation as evidence of the potential that the current system possesses and leads one to be cautiously optimistic about an increased number of yellow or orange cards in future. ${ }^{62}$

On the other hand, the fact that until recently there has only been one yellow card in almost four years of the Early Warning Mechanism's existence lends support to the view that none of the existing structures, in their current setup, are capable of delivering the type of effective coordination required to assist the chambers of national parliaments in using their Protocol (No 2) competences. Despite the aforementioned impact of COSAC, it is unlikely that the coincidence of the Member State issuing the first reasoned opinion being at the same time the chair of COSAC, and that a COSAC meeting will take place within the eight week deadline, will happen again. COSAC usually only schedules its meetings

58 Ibid., p. 7 et seq.

59 Ibid., p. 8.

60 Fabbrini/Granat, (fn. 46), p. 135.

61 Cooper, (fn. 22), p. 14.

62 Gstrein/Harvey, (fn. 32), p. 55. 
for the national parliaments' European Affairs Committees twice a year and given that national parliaments only have eight weeks to gather the votes necessary in order to trigger a yellow card procedure, it is very unlikely that COSAC meetings will be able to assist or coordinate the national parliaments in a specific case without some structural change to the way COSAC works. ${ }^{63}$ However, at the last meeting of COSAC during the Greek Council presidency there was no indication of any structural overhaul, since the focus was predominantly on the separation of tasks between the European Parliament and its national counterparts. ${ }^{64}$

It is, therefore, more likely that none of the existing structures, in their current setup, are capable of delivering the type of effective coordination required to assist the chambers of national parliaments in using their Protocol (No 2) competences on a case by case basis and thus render the mechanism more effective. ${ }^{65}$

Furthermore, from a substantive perspective, huge questions remained following the first yellow card as to the precise scope to be afforded to national parliaments when conducting a review of proposed EU legislation's compliance with the principle of subsidiarity under Protocol (No 2). This ambiguity resulted from the fact that, rather unfortunately, the Commission withdrew the Monti II proposal citing a lack of support in the EU institutions and as a result did not engage with the objections raised by national parliaments in their reasoned opinions.

\section{The Scope and Content of Subsidiarity Review}

Article 5(2)TEU provides that:

"Under the principle of subsidiarity, in areas which do not fall within its exclusive competence, the Union shall act only if and in so far as the objectives of the proposed action cannot be sufficiently achieved by the Member States, either at central level or at regional and local level, but can rather, by reason of the scale or effects of the proposed action, be better achieved at Union level".

Despite being recognized in the EU treaty framework since the Maastricht Treaty in 1993, the precise scope, content and limits to the principle of subsidiarity in EU law remain ambiguous and this has had significant implications for the Early Warning Mechanism. With regard to the reasoned opinions issued by national parliaments on the Monti II proposal, it is clear to see from the content of various parliament's submissions that a general consensus on how to correctly approach the subsidiarity review under Protocol (No 2) is

63 Ibid.

64 Minutes of the meeting of the chairperson of COSAC, Athens, Greece of 27/1/2014, p. 8.

65 Gstrein/Harvey, (fn. 32), p. 55. 
lacking. ${ }^{66}$ Several national parliaments challenged the legal basis, ${ }^{67}$ necessity ${ }^{68}$ and even the content ${ }^{69}$ of the proposed legislation rather than making explicit reference to the principle of subsidiarity. As one commentator has noted,

"In principle, subsidiarity is neatly defined in article 5(3) TEU, but in practice different parliaments use different definitions of that term and, overall, seem to require a somewhat broader interpretation., 70

As a result, the confusion over the exact boundaries of national parliament's powers of subsidiarity review has led to incoherent and often widely divergent practice from parliaments when providing reasoned opinions under Protocol (No 2).

It was noted after the Monti II proposal was withdrawn that it remained so far unclear what exactly national parliaments could refer to when claiming that the principle of subsidiarity had been violated under the Early Warning Mechanism..$^{71}$ As Fabbrini and Granat succinctly put it

"What should subsidiarity review comprise? Should national parliaments review only the strict question whether a legislative measure should be adopted by the EU or by the Member States? Or should national parliaments also consider the proportionality or necessity of the measure, the adequacy of its legal basis and its substance?"72

According to Fabbrini and Granat, allowing for a wide scope of reasoned opinions that go beyond a review of the proposal's compatibility with the principle of subsidiarity may be rejected on the basis of a textual interpretation of Protocol (No 2) since that provision explicitly only refers to subsidiarity. Additionally, in their view, a lack of a co-legislating role for national parliaments at the EU level was foreseen by the Treaty drafters and this fact, coupled with the improved capability of EU institutions such as the European Parliament, the Council and the Court of Justice to assess issues other than subsidiarity, means that the Early Warning Mechanism should not be used for purposes beyond a pure subsidiarity review. ${ }^{73}$ A narrow understanding of subsidiarity monitoring would also help to

66 See Fabrini/Granat, (fn. 46), p. 120.

67 Reasoned Opinion of the Finnish Eduskunta of 16/5/2012, Report of the Grand Committee, $\mathrm{Su}$ VM 1/2012 vp - M 2/2012 vp (courtesy translation); Avis de subsidiarité de la chamber des représentants de Belgique of 30/5/2012, DOC 53 2221/001; Reasoned opinion of the Portuguese Assembleia da Republica of 18/5/2012.

68 The Maltese parliament, along with the Finnish Eduskunta claimed that the proposal was not necessary to achieve goals of EU action in the particular policy field, see reasoned opinion of the Maltese Kamra tad Deputati, (courtesy translation), para. 1 et seq.; Reasoned Opinion of the Finnish Eduskunta, (fn. 67).

69 According to the Portuguese Assembleia, the proposals attempts at reconciling social and economic rights within the context of fundamental rights conflicted with the Portuguese constitutional tradition and the jurisprudence of the Portuguese courts, see Reasoned opinion of the Portuguese Assembleia da Republica, (fn. 67).

70 Kiiver, The Conduct of Subsidiarity Checks of EU Legislative Proposals by National Parliaments: Analysis, Observations and Practical Recommendations, ERA Forum (12) 2011, p. 7.

71 Gstrein/Zalewska, (fn. 30), p. 13.

72 Fabbrini/Granat, (fn. 46), p. 120; see also Nguyen, Die Subsidiaritätsrüge des Deutschen Bundesrates gegen den Vorschlag der EU Kommission für eine Datenschutz-Grundverordnung, ZEuS 2012, pp. 283, 293.

73 For a full account of these arguments see Fabbrini/Granat, (fn. 46). 
avoid situations where the number of reasoned opinions is sufficient to trigger a "yellow" card, but a subsidiarity breach is not proved, as in the first yellow card case of the Commission proposal on the right to strike.

On the other hand, some hold the opinion that the power of scrutiny vested in national parliaments by Protocol (No 2) should provide for a broad based review of subsidiarity that would include an evaluation of the principle of conferral, legal basis and proportionality of proposed EU legislation. ${ }^{74}$ Indeed, from a legal point of view it has been argued that each of these principles should work in combination with one another. ${ }^{75}$ For example Kiiver takes the view that an absence of competence for the EU, and even a partial encroachment upon Member State's competences by one of a proposal's provisions, is a legitimate ground for a reasoned opinion. This is because, in his view, without competence the Union is unable to achieve its aims better than the Member States, so that without competence a subsidiarity verdict can never be positive. Kiiver thus unequivocally supports the notion that legality or competence can be brought under the subsidiarity review procedure. ${ }^{76}$

More problematic than the mere academic dispute, however, is that this unclear situation forms the basis of a lack of common understanding between the individual national legislators. Some, like the German Bundesrat, that represents the Bundesländer in the national parliament, are convinced that Protocol (No 2) enables it to review proposed legislative measures in such a broad manner that the term "subsidiarity" can be seen simply as a vague headline under which each and every aspect of an EU legislative proposal may be scrutinized. ${ }^{77}$

Thankfully, a recent Commission proposal on the establishment of a European Public Prosecutors Office (EPPO) drew the second ever yellow card from national parliaments and, more importantly, led for the first time to the Commission engaging with the subsidiarity arguments put forward by national parliaments.

\section{The Second Yellow Card}

On 17 July 2013, the Commission adopted a proposal for a Council Regulation on the establishment of the European Public Prosecutors Office. ${ }^{78}$ The Commission's proposal was based on Article 86 TFEU, which empowers the Council to establish the EPPO in order to combat crimes affecting the financial interests of the Union. Article 86(1) TFEU provides for a special legislative procedure requiring unanimity in the Council and the consent of the European Parliament. ${ }^{79}$ The same treaty provision also allows for a specific procedure

74 Kiiver, The early warning system for the principle of subsidiarity, Constitutional theory and empirical reality, 2012, pp. 98-100; Ritzer/Ruttloff/Linhart, How to sharpen a dull sword: The principle of subsidiarity and its control, German Law Journal 2006, p. 737 et seq.

75 Trstenjak/Beysen, Das Prinzip der Verhältnismäßigkeit in der Unionsrechtsordnung, EuR 2012, p. 267.

76 Kiiver, (fn. 74), p. 545.

77 Nguyen, (fn. 72), pp. 283, 293.

$78 \operatorname{COM}(2013) 534$ final.

79 Under Protocol (No 22) TFEU, Denmark does not take part in the adoption of the proposed Regulation. The United Kingdom and Ireland have not notified their wish to take part in the adoption and application of this Regulation under Protocol (No 21) TFEU. 
according to which the proposal can be adopted through enhanced cooperation in the absence of unanimity in the Council. The Treaty requires for this procedure the participation of at least nine Member States and an absence of consensus in the European Council. In such a case the authorisation to proceed with enhanced cooperation shall be deemed to be granted without the need of a formal act of the Council.

The proposal was part of a package of measures aimed at better protecting the Union's financial interests. ${ }^{80}$ According to the proposal, the European Public Prosecutor's Office would be tasked with investigating, prosecuting and bringing to judgement the perpetrators of offences affecting the Union's financial interests. ${ }^{81}$ Exclusive competence was to be granted to EPPO for all crimes affecting the financial interests of the Union and this included non-cross-border cases. ${ }^{82}$ The EPPO was to be established as a body of the Union with a decentralised structure which, for most of its activities, would rely on national investigation and prosecution authorities, and on national law. This structure was to consist of a single organisation with two layers: a central unit which would essentially supervise, coordinate and, where necessary, direct investigations and prosecutions carried out in the Member States, and the European Delegated Prosecutors, who would generally carry out such investigations and prosecutions autonomously. These European Delegated Prosecutors would have been part of both the European Public Prosecutor's Office and national prosecution services.

Owing to the fact that the EPPO proposal had its legal basis in Article 86 TFEU, the threshold of votes required for national parliaments to initiate the Early Warning Mechanism, as provided for in Article 7(2) of Protocol (No 2), was one quarter of the total votes allocated to the national parliaments. ${ }^{83}$ Within the deadline set out in Article 6 of Protocol (No 2), fourteen chambers of national parliaments ${ }^{84}$ had sent reasoned opinions to the Commission setting out their views with regards to the EPPO proposals' compatibility with the principle of subsidiarity. As a result, the subsidiarity control mechanism provided for in Article 7(2) of Protocol (No 2) (yellow card) was triggered, ${ }^{85}$ meaning that the Commission was obliged to review the proposal and decide to maintain, ammend or withdraw it whilst giving reasons for such a decision. The threshold of Article 7(3) of Protocol (No 2) (orange card) was not reached.

Unfortunately, the detailed account of how various national parliaments were able to cooperate to bring about the issuance of a yellow card with regards to the Monti II regulation has not yet been made available for the EPPO proposal. That being said the response of the Commission certainly requires further scrutiny given that it was the first time that a concrete response has been given on the precise scope of national parliaments' subsidiarity review in the Early Warning Mechanism.

$80 \operatorname{COM}(2013) 535$ final.

81 COM (2013) 534 final.

82 COM (2013) 534 final, Article 11(2).

83 As opposed to the "normal" threshold of one third of the votes.

84 See Communication on the review of the proposal for a Council Regulation on the establishment of the European Public Prosecutor's Office with regard to the principle of subsidiarity, in accordance with Protocol (No 2), COM (2013) 851 final, Annex 1.

85 The issued reasoned opinions represented 18 votes out of the 56 assigned to national parliaments and thus exceeded the one quarter threshold. See COM (2013) 851 final, Annex 1. 


\section{National Parliaments' Observations and the Response of the Commission}

Before moving to consider the response of the Commission, it is worthwile having a closer look at the specific objections that were raised by national parliaments. Predictably, some parliaments, such as the British, the Dutch, the Irish and the Hungarian raised the traditional argument that criminal investigations and prosecutions are primarily a matter of national sovereignty and that the establishment of a supranational EPPO would limit their national competence in a disproportionate way. ${ }^{86}$

In addition, the granting of exclusive competence to EPPO for all crimes affecting the financial interests of the Union, including non-cross-border cases, was deemed to have been problematic for parliamentary chambers in Poland, Romania, The Netherlands, Hungary, Germany and Britain. ${ }^{87}$ Other opinions noted that many offences affecting the financial interests of the EU are situated at a purely national level and are often linked to other types of fraud or criminality and that as a result the granting of wide ancilliary competence to EPPO for offences which are inextricably linked with EU fraud was inappropriate e.g. the Romanian Chamber of Deputies, the Dutch Senate, the German Bundesrat and the Cyprus House of Representatives. ${ }^{88}$

Interestingly, Germany argued that the subsidiarity principle would be violated if not all Member States participated in the EPPO initiative, with the consequence that the possibility of enhanced cooperation under Article 86(1) TFEU being used was implicitly ruled out. ${ }^{89}$

In its reply to the national parliaments, the Commission began by explicitly stating that:

"The procedure of Article 7(2) of Protocol (No 2) is exclusively focused on the principle of subsidiarity and in reasoned opinions within the meaning of Article 6 of Protocol (No 2) national Parliaments need to state why they consider that a draft legislative act does not comply with that principle. As a result, legal or policy arguments not connected to subsidiarity are not examined in detail in this Communication." 90

In light of this, it is clear to see that the Commission was in principle unwilling to accept reasoned opinions from national parliaments that sought to challenge the proposal on grounds unrelated to subsidiarity through the mechanism provided in Protocol (No 2). However, having unambiguously set this narrow reading of the Early Warning Mechanism, the Commission, in the immediately ensuing sentence, conteded:

"The Commission is however well aware that the limits of the principle of subsidiarity are not easy to trace and has therefore adopted an open attitude towards the reasoned opinions, interpreting their arguments, insofar as possible, in the light of the principle of subsidiarity." 91

86 The respective reasoned opinions may be found on the IPEX website, www.ipex.eu/IPEXL-WEB/ dossier/document/COM20130534.do\#dossier-APP20130255 (25/6/2014).

87 Ibid.

88 Ibid.

89 Franssen, National Parliaments Issue Yellow Card against the European Public Prosecutor's Office, European Law Blog of 4/11/2013, http://europeanlawblog.eu/?p=2025 (25/6/2014).

90 COM (2013) 851 final, p. 4.

91 Ibid. 
The Commission then set out what, in its view, subsidairity review entailed, stating that

"The subsidiarity test involves two closely interrelated questions: first, whether the proposed action can or cannot be sufficiently achieved by the Member States acting on their own; and second, whether the action can be, by reason of its scale or effects, better achieved at Union level. Both steps are connected, as the insufficiency of Member State action will often lead to a finding that Union action will better achieve the proposed policy objective. The text of Article 5(3) TEU makes the connection clear ('but can rather') and the Court of Justice of the European Union has often carried out one single analysis of the two questions, implicitly recognising a certain margin of discretion to the Union institutions." 92

Then, in relation to the issue of competence, it was noted that under Article 5(3) TEU the principle of subsidiarity does not apply to the exclusive competences of the Union and since the competence to establish the EPPO (Article 86 TFEU) was not among the exclusive competences set out in Article 3 TFEU and is not an exclusive competence by nature (i.e. a competence that, although it is not listed in Article 3 TFEU, could only be exercised by the Union and for which the subsidiarity analysis is irrelevant), the principle of subsidiarity applied to Article 86 TFEU. ${ }^{93}$

However, in the Commission's view, the drafters of the Treaty expressly provided for the possibility of establishing the EPPO in Article 86 TFEU and that, as a result, this provision gives a strong indication that the establishment of the EPPO cannot be considered per se and in the abstract to be in breach of the principle of subsidiarity. Accordingly, what has to be examined is whether the insufficiency of Member State action and the addedvalue of Union action justify the establishment of the EPPO and that issue has to be judged in light of the different aspects of the proposal, i.e. the way in which the Office would be established and the rules and procedural powers that would frame it. ${ }^{94}$

The Commission then distinguished between arguments relating to the principle of subsidiarity, or that could be interpreted as subsidiarity concerns, and other arguments relating to the principle of proportionality, to policy choices unrelated to subsidiarity, or to other policy or legal issues. In its view, the following arguments could be summarised as not falling within the parameters of the subsidiarity review as set out in Protocol (No 2): ${ }^{95}$

- The Regulation was too far-reaching;

- The European Public Prosecutor's Office's powers were too far-reaching and should be reserved to national authorities;

- The Regulation goes beyond what is necessary to achieve its objective;

- The Regulation may violate the protection of fundamental rights guaranteed by the Czech Constitution and the Charter;

- The Regulation would create disadvantages for Member States in that they lose the capacity to prioritise prosecution activities within their own criminal justice system;

92 Ibid., p. 4 making reference to, for example, CJEU, case C-58/08, Vodafone, ECR 2010, I-4999, para. 72; CJEU, case C-377/98, Netherlands v Parliament and Council, ECR 2001, I-7079, para. 32.

$93 \operatorname{COM}(2013) 851$ final, p. 4.

94 Ibid.

95 Ibid., p. 5. 
- Article 26 of the proposal contains investigation measures which are not allowed under national law in all Member States and this may undermine the effective protection of the rights of suspects.

According to the Commission, these arguments would, despite falling outside the acceptable scope of review under the Early Warning Mechanism, nevertheless be duly taken into account in the process of negotiating the proposal moving forward and would be addressed in the ensuing political dialogue. ${ }^{96}$

In terms of the reasoned opinions that were deemed relevant to questions of subsidiarity, the Commission dealt with:

- The reasoning concerning subsidiarity;

- The alleged sufficient character of existing mechanisms;

- The added-value of the proposal;

- Issues relating to the structure of the European Public Prosecutor's Office;

- Issues relating to the nature and scope of its competences.

In concluding its analysis of the opinions raised by national parliaments, the Commission concluded that its proposal not only complied fully with the principle of subsidiarity as enshrined in Article 5(3) TEU, but also that neither a withdrawal, nor even an amendment, was necessary. The key issue here was therefore how one should understand the legal dimension of the subsidiarity principle, especially with regard to Protocol (No 2) of the Treaty. ${ }^{97}$ Given that the legislators on the European and national levels have thus far been incapable of delivering a common understanding of this principle, it is highly likely that the European Court of Justice in Luxembourg will have to fill this gap through its jurisprudence.

\section{The problem with Ex Post Subsidiarity Review}

By reaching the conclusion that there was no subsidiarity violation and maintaining its proposal for a EPPO without amendments, the Commission confirmed what many had feared from the outset of the Early Warning Mechanism: that national parliaments lacked any real power when it came to subsidiarity control since they were only really a subordinate safeguarding mechanism under the Lisbon Treaty. ${ }^{98}$ Furthermore, the Commission's insistence on maintaining the EPPO legislation has arguably changed the nature of the Early Warning Mechanism by setting a precedent for the Commission over-ruling the views of national parliaments. This may undermine the system in the future and lead to a reluctance amongst national parliaments to engage in the work of issuing reasoned opinions. ${ }^{99}$

As a result of maintaining the proposal, the only course for legal redress left open to national parliaments would be to launch an action for annulment before the CJEU once the final regulation had been enacted. According to Article 8 of Protocol (No 2):

96 Ibid.

97 Goldini, (fn. 3), p. 7.

98 Von Bogdandy/Bast, (fn. 19), p. 303.

99 Terry, Close the Gap: Tackling Europe's Democratic Deficit, Electoral Reform Society, www.electoral-reform.org.uk/images/dynamicImages/file/Close $\% 20$ the $\% 20 \mathrm{Gap} \% 20 \mathrm{FOR} \% 20$ ONLINE\%204.pdf (25/6/2014), p. 34. 
"The Court of Justice of the European Union shall have jurisdiction in actions on grounds of infringement of the principle of subsidiarity by a legislative act, brought in accordance with the rules laid down in Article 263 of the Treaty on the Functioning of the European Union by Member States, or notified by them in accordance with their legal order on behalf of their national Parliament or a chamber thereof."

The problem with this mechanism, however, regards standing to bring an action under Article 263 TFEU. It is to be noted that there are three types of applicants that may lodge applications before the Union Courts. The literature consistently refers to these as "Privileged Applicants" (Member States, European Parliament, Council or Commission), "SemiPrivileged" (Court of Auditors, European Central Bank and Committee of Regions) and "Non-Privileged" (natural or legal persons). 100 "Privileged applicants" represent a public interest that requires judicial protection, "Semi-Privileged Applicants" protect their own institutional competences and "Non-Privileged Applicants" have to prove that an act is addressed to them, is of direct and individual concern to them, or is a regulatory act which is of direct concern to them and does not entail implementing measures. ${ }^{101}$

As can be seen from the above categories of applicants, though, national parliaments do not have independent standing before the CJEU since they are dependent upon national governments to raise such an action. The final stipulation of Article 8 of Protocol (No 2), namely "or notified by them in accordance with their legal order on behalf of their national Parliament or a chamber thereof" makes it clear that national parliaments have no way of compelling their government to launch an action for annulment before the CJEU against a measure of EU law in the absence of national rules allowing for such a process. ${ }^{102}$ Indeed, as von Bogdandy and Bast noted, remarkably Article 8 of Protocol (No 2) does not grant national parliaments a right of action to the CJEU and instead makes such an action dependent on national law and the "normal" requirements of an action for annulment. ${ }^{103}$

As a result the entire purpose of the Early Warning Mechanism - namely the enhancement of the role of national parliaments in the EU legislative process in light of their perceived loss of power following successive treaty ammendments - is considerably undermined.

A further problem here is that, when it comes to ex post scrutiny of EU legislation's compliance with the principle of subsidiarity via an action before the CJEU, national parliaments hold widely divergent powers within their domestic political systems with regards to their control over EU matters and their ability to compel their government to act. For example, the Finnish Eduskunta has a strong influence on EU affairs in comparison to many other Member States' national parliaments. ${ }^{104}$ In Finland, a Grand Committee of the parliament that deals directly with issues related to EU law decides the Eduskunta's position

100 Dashwood/Wyatt, Wyatt and Dashwood's European Union Law, 2011, p. 155; Craig/De Bur$c a,($ fn. 14), p. 490 et seq.

101 For a general overview see ibid., p. 498 et seq.; see also Granat, (fn. 1), p. 4.

102 Ibid., p. 7.

103 Von Bogdandy/Bast, (fn. 19), p. 303; Piris, (fn. 3), p. 130.

104 Hegeland, The European Union in National Parliaments: Domestic or Foreign Policy?, A Study of Nordic Parliamentary Systems, in: O'Brennan/Raunio (eds.), National Parliaments within the Enlarged European Union, From Victims of Integration to Competitive Actors?, 2007, p. 95. 
with regards to launching an action before the CJEU by issuing a report and recommendation in plenary session. If this report from the Grand Committee finds a breach of subsidiarity, the parliament instructs the government to take action before the CJEU. ${ }^{105}$

In stark contrast to the powers of the Finnish Eduskunta, parliaments in Italy, Luxembourg and Spain impose high barriers on subsidiarity actions originating from parliamentary chambers. Generally speaking, the parliaments in these countries have no direct control or influence over their government's policy towards the EU with non binding hearings, discussions, recommendations etc. being the norm. Governments can simply overrule or dismiss calls from parliament to launch a subsidiarity review before the CJEU. ${ }^{106}$

From a different perspective, the Early Warning Mechanism set out in Protocol (No 2) makes explicit reference to legislative acts only and this could - given the narrow definition of legislative acts in Article 289 TFEU $^{107}$ - significantly compromise the effective safeguarding of subsidiarity of other legislative acts, including those adopted by the Council based on a treaty provision that was classified as allegedly "non legislative". ${ }^{108}$

\section{E. Possible Solutions}

\section{Procedural}

One possible improvement to the subsidiarity review mechanism - and something that was proposed in relation to ensuring compliance with the principle of subsidiarity long before the drafting of the Lisbon Treaty - would be to set up a subsidiarity committee composed of national parliamentarians that would have consultative powers and could be worked into the legislative process. ${ }^{109}$ However, this proposal would likely further complicate what is an already complex EU institutional structure and arguably take Europe further away from the everyday citizen - thus frustrating the very goal that the subsidiarity principle explictly sets out to achieve. Indeed, as was noted in the minutes of the COSAC meeting in January 2014, summarizing the statement of Carlo Casini who is the current Chair of the Committee of Constitutional Affairs in the European Parliament:

"[...], the relationship of the EP and of national parliaments could not be one of competition or contradiction, but of collaboration." 110

More radically, some have supported the idea of introducing a so-called "green card" for national parliaments which would give them the possibility to launch a legislative process

105 COSAC Annex to Thirteenth Bi-Annual Report on Developments in European Union Procedures and Practices Relevant to Parliamentary Scrutiny: Replies of National Parliaments and the European Parliament, 2010, www.cosac.eu/documents/bi-annual-reports-of-cosac/ $(25 / 6 / 2014)$.

106 Granat, (fn. 1), p. 11 et seq.

107 CJEU, case C-583/11, Inuit Tapiriit Kanatami and Others.

108 See von Bogdandy/Bast, (fn. 19), p. 303 at fn. 202.

109 Pernice, Kompetenzabgrenzung im Europäischen Verfassungsverbund, JZ 2000, p. 876; Siedentop, Democracy in Europe, 2000, p. 147.

110 Minutes of the meeting of the chaipersons of COSAC, Athens, Greece of 27/1/2014, p. 8. 
in the EU. ${ }^{111}$ As the chairperson of the European Affairs Committee in the Danish parliament, Eva Kjer Hansen has argued that national parliaments should have the right to initiate legislation. This would work by national parliamentarians going to their constituencies and inviting citizens to put forward ideas that could, if they receive local, regional, national and pan-European support, be turned into EU legislation. ${ }^{12}$ On the face of it, however, the introduction of such a new competence for national parliaments seems to be quite unlikely since the current Lisbon Treaty system clearly indicates that the only institution which has a genuine right to legislative initiative in the EU is the European Commission. ${ }^{113}$

As a more practical alternative, it is submitted that in order to improve the cooperation of European legislators on drafts of the European Institution initiating legislation (usually the Commission), the already existing networks such as the Inter-parliamentary Exchange Platform or the already mentioned Conference of Community and European Affairs Committees of Parliaments of the European Union have to be upgraded. ${ }^{114}$ The fact that the first issuing of a yellow card was arguably only possible because of enhanced cooperation during the aforementioned inter-parliamentary meeting in Denmark should be considered as evidence of an underlying problem within the system's current structure. Borrowing the principle approach from the Committee of Regions and its Subsidiarity Monitoring Network, national parliaments should develop their activities further and commonly appoint a Rapporteur for monitoring a specific legislative proposal by the European institution responsible for its initiation. Through this, the process of subsidiarity review for a single act would become clearer and more easily manageable.

These rapporteurs, who should be highly qualified Members of Parliament with their main duties in one Member State, would have the function of analysing the Commission's proposal and gathering opinions and statements of all Member States' legislative assemblies in order to find common ground for action. Rapporteurs should be chosen through a standardised procedure in a common forum, most appropriately IPEX. They should start their activities as early as possible in the draft legislative process since they will have a limited amount of time to work on the reports; especially considering the eight week deadline parliaments have to meet in order to provide their opinions to the EU. It may be necessary to set up additional supporting mechanisms on the side of the European Commission. They should be in accordance with certain criteria such as: the importance of the specific policy area of the proposal for the Member State where the Members of Parliament come from and maybe also the region the Member of Parliament represents; his or her professional skills and relation to the topic; the general division of such tasks between the different Member States in order to maintain a necessary balance etc. It seems appropriate to have a non-enumerative set of criteria as a guideline for choosing the rapporteurs, leaving the committee of appointment a certain margin of appreciation in order to react to special circumstances that might arise in individual cases.

111 House of Lords European Union Committee report, (fn. 53), p. 16.

112 Kjer Hansen, Why the EU must boost the powers of national MPs, Europe's World Spring 2014, pp. 52-58.

113 Articles 17(2) and 11(4) TEU, Articles 225, 241 TFEU.

114 See http://ipex.eu (25/6/2014). 
Based on their reports - which would be drafted with support from a permanent expert committee at IPEX, specifically set up for this procedure - national legislators would then decide whether or not to take action having considered the recommendations of the rapporteurs. Depending on the political sensitivity of the issue, the use of an increased number of rapporteurs is certainly possible. However, the overall number should be limited to three rapporteurs, since more contributors would undermine the main objective of introducing such a mechanism: namely the streamlining of the process by providing a clear and highly qualified opinion on the topic.

\section{Substantive: A Common Understanding of Subsidiarity}

As was discussed above in relation to the proposal for establishing a EPPO, the Commission responded to the reasoned opinions of national parliaments by endorising a narrow reading of the scope of subsidiarity review accorded to national parliaments in Protocol (No 2) whilst at the same time entertaining some arguments that went beyond this narrow scope. As a result of this somewhat flexible approach, it is likely that this will not be the end of the story with regard to the scope and content of subsidiarity review under the Early Warning Mechanism. It is likely that national parliaments will continue to make reference to more wide-ranging concerns such as competence and proportionality than the Commission's suggested narrow, subsidiarity only reading of the Early Warning Mechanism. Regardless as to one's view as to what should be acceptable here, there can be no doubt that a lack of common understanding may hinder the effectiveness of the Early Warning Mechanism mechanism as a whole.

As a solution it is submitted that in order to improve this unsatisfactory situation, an agreement or "common understanding" between the national legislators of the EU Member States is necessary. ${ }^{115}$ By defining a framework within which to conduct subsidiarity control, the current patchwork approach would be replaced by a more coherent solution. As a result, the position of national legislators would be dramatically improved. It is therefore conditio sine qua non to transform the procedure from its current status as a merely political gesture into an effective tool of political cooperation and control.

Member States have to express their consent to adhere to common principles or standards of review within the Early Warning Mechanism and in so doing, enhance the prospects of parliamentary coordination and cooperation in submitting national opinions. This would result in an amicably agreed and politically endorsed definition of how the subsidiarity review under Protocol (No 2) should operate. ${ }^{116}$ Technically, the agreement should take the form of an international treaty or a common declaration; the latter being more suitable due to its less invasive character.

Regarding the content of such a common understanding it seems advisable to modify or even commit in its entirety to the "Subsidiarity and Proportionality Assessment Grid", a

115 Gstrein/Harvey, (fn. 32), p. 57; Pliakos, in: House of Lords European Union Select Committee, (fn. 32), pp. 160-166.

116 Once this "common understanding" is adopted there may be challenges from other European Institutions resulting in legal proceedings, but such a process might prove to be positive in terms of fostering the development of a clear legal definition of the principle of subsidiarity. 
tool developed by the European Union's Committee of Regions. ${ }^{117}$ This set of criteria does not only offer a sound basis for evaluation, it is also already being used by the Committee of Regions and the European Commission. ${ }^{18}$ Therefore, by committing to this set of criteria, national legislators would have a valuable basis upon which to launch their activities. Additionally, such a move would present an opportunity to create a circle of regional, national and supranational institutions using and developing the same set of criteria for subsidiarity review. Especially when looking at the fruitful development of the Committee of Regions "Subsidiarity Monitoring Network" and the evolution of its most recent initiative, the "Regional Parliamentary Exchange" (REGPEX), ${ }^{119}$ one submits that this is the correct manner in which to proceed.

\section{F. Looking to the future}

Moving to consider the prospects of the Early Warning Mechanism in the future, it is submitted that a common understanding of the type envisaged above is likely to become all the more necessary in light of renewed calls for a substantial change to the relationship between national parliaments and the EU legislative process.

In the Netherlands, for example, Dutch Foreign Minister Frans Timmermans presented in June 2013 a letter summarising the outcome of a "subsidiarity review" carried out by the Dutch government. The letter unequivocally states that certain policy fields in which the EU currently has competence would be better left exclusively for the Member States to deal with. Although not explicitly setting out how this is to be achieved, calls for some form of enhanced role for national parliaments in reviewing compliance with subsidiarity may be reasonably expected. ${ }^{120}$

In Britain, Foreign Secretary William Hague and his opposition counterpart Douglas Alexander have also expressed a desire to radically alter the current delineation of competences between the EU and national parliaments. In their view the current yellow card procedure should be upgraded to a red card or emergency brake procedure that would allow national parliaments to block legislative proposals. ${ }^{121}$

Regardless of how these initiatives play out in the future, and regardless of how the outcomes of the European Elections in May 2014 will influence the political landscape in the European Union, there can be no doubt that increased levels of attention being paid to the relationship between the EU and national parliaments will necessitate a proper understanding of how the principle of subsidiarity is to operate in practical terms. It would be a significant improvement of the national legislators' postitions within the EU, if they would

117 See for details https://portal.cor.europa.eu/subsidiarity/thesmn/Pages/default.aspx (25/6/2014); Committee of Regions, Subsidiarity annual report 2012, R/CdR 1335/2013.

118 Report from the Commission on subsidiarity and proportionality, COM (2009) 504 final, p. 4.

119 Committee of Regions, (fn. 117), p. 4 et seqq.

120 Euractiv News of 25/6/2013, Dutch 'subsidiarity review' strikes a chord with UK euro critics, www.euractiv.com/future-eu/dutch-subsidiarity-review-strike-news-528833 (25/6/2014).

121 London Evening Standard of 1/6/2013, Hague urges EU red card system, www.standard.co.uk/ panewsfeeds/hague-urges-eu-red-card-system-8638827.html (25/6/2014); Douglas, Britain's future in Europe, speech delivered 17/1/2013 at Chatham House, London, www.chathamhouse.org/events/view/188423 (25/6/2014). 
succeed in this task. On the other hand, if national parliaments fail to create a common framework and define the subsidiarity principle sufficiently, they run the risk of losing the trust of their citizens when it comes to European political matters. New instruments like the European Citizens' Initiative laid down in Article 11(4) of the TEU recently seem to be gaining more momentum. ${ }^{122}$ Furthermore, if the CJEU continues to foster the protection of fundamental rights by sticking to it's new understanding of the Charter of Fundamental Rights of the EU, citizens might well ask themselves whether holding on to national fora makes sense. In this regard it could well come to pass that citizens perceive the type of protection they receive from the judges in Luxembourg to be more effective, as could be argued in the case of data retention. ${ }^{123}$ All of a sudden, Brussels might win the hearts of European citizens because they feel that European Institutions protect their interests more effectively than their national counterparts and this would further weaken the role of national parliaments.

Overall it has to be clearly acknowledged that legislative procedures on the EU level will never be "as close" to the European citizen as their national equivalents. More importantly, however, it is questionable if understanding the issue of "democratic legitimacy" in this way is appropriate, since it is not the purpose of European institutions to replace those already existing at the national level. Clearly, it is the task of European legislation to solve European problems. Nothing more and nothing less. Therefore, it is wrong to include national parliaments in the process of European legislation as such. However, what is necessary is an improved procedure in order to clarify the sphere for national and European legislation. It is time to transform the principle of subsidiarity from a political token gesture into a legally feasible concept.

The intention of Protocol (No 2) of the Treaty of Lisbon was to clarify the dimension of subsidiarity - transforming it from a gambling table of politics into a legal principle with the power to harmonize the scope of action of legislators in Europe for the common good. It is time to live up to this commitment.

\section{G. Conclusion}

The Early Warning Mechanism included in Protocol (No 2) to the Lisbon Treaty was intended to give national parliaments more influence in the European legislative process given their gradual loss of power over successive rounds of treaty amendment. Now operational for almost half a decade, it is clear to see from the very low number of yellow or orange cards issued by national parliaments to date that the subsidiarity control procedure in its current format has been largely unsuccessful. Whilst it is certainly true that on occcasion national parliaments have demonstrated an ability to collectively consult with one another and even act in concert to oppose EU legislative proposals, these instances have been isolated, with the case for reforming the system growing ever stronger.

122 European Commission, Daily News Briefing, MEX/14/0228 of 28/2/2014.

123 Cf. judgements of the CJEU on the data retention directive (C-293/12 and C-594/12) and in Akerberg-Fransson (C-617/10). 
In terms of substance, it has been suggested that a comprehensive definition of the principle of subsidiarity and the precise scope of its operation within the Early Warning Mechanism is lacking and this has substantially hindered the overall efficacy of national parliaments in the European legislative process. In order to address this problem, Member States should adopt an amicably agreed and politically endorsed definition of how the subsidiarity review under Protocol (No 2) should operate in order to enhance the prospects of parliamentary coordination and cooperation in submitting national opinions to the European institution initiating a particular piece of legislation (usually the Commission).

The need to improve the functioning of the Early Warning Mechanism is today all the more necessary given the growing number of Member State governments who, under increasing pressure from strengthened eurosceptic movements, have voiced concerns over the role of national parliaments in the EU legislative process and begun suggesting some radical re-allocation of competences between the national and European levels. The principle of subsidiarity has at its very core a desire to ensure that decisions effecting the citizens of Europe be taken as closely to them as possible. It is for this reason that national parliaments must be seen to be doing more to reflect the concerns of their citizens at the European level. 